\title{
Peningkatan Kemampuan Membuat Surat dan Laporan menggunakan Ms.Word pada Siswa MA Raudatul Irfan
}

\author{
Adhi Kusnadi ${ }^{*}$, Marlinda Vasty Overbeek ${ }^{2}$, Yaman Khaeruzzaman ${ }^{3}$, Moeljono \\ Widjaja $^{4}$, Alethea Suryadibrata ${ }^{5}$ \\ 1,2,3,4,5Informatika, Universitas Multimedia Nusantara, Indonesia, 15227
}

E-mail: adhi.kusnadi@umn.ac.id

DOI: https://doi.org/10.37339/jurpikat.v1i2.341

\section{Info Artikel:}

Diterima :

2020-10-18

Diperbaiki :

2020-10-27

Disetujui :

2020-10-27

Kata kunci: MS.Office, MS.Word, Pelatihan, Surat, Laporan
Abstrak: Kegiatan pelatihan ini bertujuan untuk meningkatkan kemampuan siswa/siswi MA Raudatul Irfan dalam penggunaan MS.Office, terutama MS.Word. Peningkatan kemampuan siswa/siswi akan meningkatkan peluang mereka untuk memasuki jenjang pendidikan lebih tinggi dan dunia kerja. Kegiatan ini dilaksanakan selama dua hari dimulai dari pagi jam 8.00 WIB sampai selesai. Banyaknya jumlah siswa/siswi yaitu berjumlah 80 orang ditambah staf dan guru sebanyak 10 orang, maka untuk meningkatkan efektifitas dalam pelatihan di laboratorium Kampus UMN, peserta dibagi dua kelompok sebanyak 40 orang untuk setiap kelasnya. Metode yang digunakan dalam pelatihan ini adalah demontrasi dan contoh. Pada awal sesi peserta akan diperkenalkan pada komputer, sistem operasi, dan MS.Office, kemudian diakhiri dengan evaluasi dan latihan. Dengan mengikuti pelatihan ini, siswa/siswi akan meningkat kemampuannya dalam menggunakan komputer terutama MS.Office dengan tujuan utama membuat surat dan laporan menggunakan MS.Word. Secara keseluruhan kegiatan ini berlangsung dengan lancar dan baik, dan hasil latihan/evaluasi yang baik dengan ratarata indeks prestasi 2,7 dari skala 1-4. 
Keywords: MS.Office, MS.Word, Training, Letter, Report
Abstract: This training activity aims to improve the ability of MA Raudatul Irfan students in using MS.Office, especially MS.Word. Increasing the ability of students will increase their chances of entering higher education and profession. This activity is carried out for two days starting from 8.00 WIB until finished. The number of students is 80 people, 10 staff and teachers. To increase the effectiveness of training in the UMN Campus laboratory, participants were divided into two groups of 40 people for each class. The methods used in this training are demonstrations and examples. At the beginning of the session, participants will be introduced to computers, operating systems, and MS.Office. This training is ended with evaluation and exercises. By participating in this training, students will improve their ability to use computers, especially MS.Office, with the main objective of making letters and reports using MS.Word. Overall, this activity ran smoothly and well, and the results of the training / evaluation were good with an average grade of 2.7 from a scale of $1-4$

\section{Pendahuluan}

Pada saat ini kemampuan menggunakan MS.Office sudah menjadi kemampuan yang harus dimiliki oleh semua siswa/siswi yang berminat untuk melanjutkan ke jenjang pendidikan yang lebih tinggi atau memasuki dunia kerja. Kemampuan ini sudah menjadi kemampuan dasar yang harus dimiliki, hampir semua aspek membutuhkan keahlian ini (Dahar, 2012)(Arikunto, 2007), misal membuat surat, laporan keuangan dan lain sebagainya. Badan Pusat Statistik (BPS) menyatakan Indeks Pembangunan Teknologi, Informasi, dan Komunikasi (IP-TIK) Indonesia pada 2017 berada di angka 4,99 dari skala 1-10 (BPS, 2018). Indeks ini meningkat dari tahun sebelumnya yang hanya sebesar 4,34 pada 2016 dan 3,88 pada 2015. Indeks ini memang meningkat dari tahun sebelumnya. Namun sejatinya indeks pembangunan TIK Indonesia masih belum memuaskan. Pasalnya, indeks masih belum mencapai skala 5 dari 10, ini menunjukkan Indonesia masih jauh dari angka 10.

Universitas Multimedia Nusantara (UMN) yang memiliki kewajiban melaksanakan Tri Darma Perguruan Tinggi, juga yang memiliki kewajiban ikut mencerdaskan kehidupan bangsa. Dituntut ikut membantu masyarakat sekitar dalam meningkatkan kemampuan TIK masyarakat, terutama siswa/siswi sekolah yang memiliki infrastruktur ITK dalam dalam tahap pengembangan (Dunlosky, 
Rawson, Marsh, Nathan, \& Willingham, 2013). Hal ini sudah menjadi kegiatan rutin yang dilakukan oleh UMN. Terutama Prodi Teknik Informatika dengan mengadakan kegiatan workshop yang berhubungan dengan TIK(Martin, Kolomitro, \& Lam, 2014).

Terdapat sebuah sekolah menengah atas MAS Raudatul Irfan yang beralamat di Jl. TMP Arya Wangsakara Kp. Lengkong Ulama, yang berjarak tidak lebih dari 10 Km dari kampus UMN. Dimana sedang berusaha membangun infrastruktur TIK di lokasi sekolahnya, tetapi masih terkendala oleh biaya dan tempat. Oleh karena itu diadakan kerjasama antara MA Raudatul Irfan dan UMN, sehingga siswa/siswa dapat tetap mendapatkan pembelajaran TIK. Dengan mengadakan workshop/pelatihan penggunaan MS.Office untuk siswa/siswi MA Raudatul Irfan dengan instruktur dari dosen-dosen Informatika yang sangat berpengalaman dan menguasai bidang informatika.

Target luaran dalam Program ini dapat dijelaskan sebagai berikut:

1. Tujuan Pelatihan

- Membantu guru-guru dalam meningkatkan kemampuan siswa/siswi menguasai bidang TIK terutama MS.Office.

- Memperkenalkan dan memberikan keterampilan dasar MS. Office kepada siswa/siswi MA Raudatul Irfan.

2. Sasaran Pelatihan

- Meningkatkan kemampuan guru dalam proses pengajaran bidang TIK (Jevana, 2017).

- Siswa/i menguasai kemampuan dasar MS.Office.

\section{Metode}

Dalam pelaksanaan program pelatihan ini, tim telah melakukan penyusunan rencana metode yang akan dilakukan selama proses awal sosialisasi dan rencana selama kegiatan berlangsung (Fajriah, 2017). Adapun dalam sosialisasi awal, tim terlebih dahulu telah berkunjung ke MA Raudatul Irfan Lengkong Tangerang. Dalam sosialisasi awal, tim memiliki tujuan agar terjadi komunikasi timbal balik tentang bagaimana cara yang efektif melaksanakan kegiatan ini.

Didapat metode yang paling cocok adalah "Metode Demonstrasi dan Contoh" Suatu demonstrasi menunjukkan dan merencanakan bagaimana suatu pekerjaan atau bagaimana sesuatu itu dikerjakan (Hoque, 2016)(Hackathorn, Solomon, Blankmeyer, Tennial, \& Garczynski, 2011). Metode ini melibatkan penguraian dan 
memeragakan sesuatu melalui contoh-contoh. Metode ini sangat mudah pengajar dalam mengajarkan peserta mengenai aktivitas nyata melaui suatu tahap perencanaan dari "Bagaimana dan apa sebab" peserta mengerjakan pekerjaan yang ia kerjakan. Metode ini sangat efektif, karena lebih mudah menunjukkan kepada peserta cara mengerjakan suatu tugas, karena dikombinasikan dengan alat Bantu belajar seperti: gambar-gambar, teks materi, ceramah, diskusi (Paolini, 2015).

Susunan Acara Hari Pertama dan Kedua yaitu Tanggal 6-7 November 2019 disajikan pada Gambar 1 dan Gambar 2.

\begin{tabular}{|c|c|c|c|}
\hline $\begin{array}{l}08.00-08.15 \\
\text { Isi daftar hadir dan } \\
\text { persiapan } \\
\text { (Ruang Lab Komputer } \\
\text { B501 dan B502) }\end{array}$ & $\begin{array}{l}\text { 08.15-10.15 } \\
\text { Sesi } 1 \text { : Pembuatan } \\
\text { Surat Lamaran dan CV } \\
\text { (Ruang Lab Komputer } \\
\text { B501 dan B502) }\end{array}$ & $\rightarrow$ & $\begin{array}{l}10.15-10.30 \\
\text { Istirahat } \\
\text { (Selasar Lab) }\end{array}$ \\
\hline & & & $\nabla$ \\
\hline & $\begin{array}{l}10.15-10.30 \\
\text { Istirahat } \\
\text { (Kantin) }\end{array}$ & 4 & $\begin{array}{l}\text { 10.30-12.00 } \\
\text { Sesi } 2 \text { : Membuat } \\
\text { Laporan } \\
\text { (Ruang Lab Komputer } \\
\text { B501 dan B502) }\end{array}$ \\
\hline
\end{tabular}

Gambar 1. Susunan Acara Hari Pertama Tanggal 6 November 2019

\begin{tabular}{|c|c|c|}
\hline $\begin{array}{l}\text { 08.00-08.15 } \\
\text { Isi daftar hadir dan } \\
\text { persiapan } \\
\text { (Ruang Lab Komputer } \\
\text { C706 dan C708) }\end{array}$ & & $\begin{array}{l}\text { 08.15-09.00 } \\
\text { Review } \\
\text { (Ruang Lab Komputer } \\
\text { C706 dan C708) }\end{array}$ \\
\hline & & $\downarrow$ \\
\hline $\begin{array}{l}12.00 \\
\text { Makan siang } \\
\text { (Selasar Lab) }\end{array}$ & & $\begin{array}{l}\text { 09.00-12.00 } \\
\text { Ujian/sesi } 3 \\
\text { (Ruang Lab Komputer } \\
\text { C706 dan C708) }\end{array}$ \\
\hline
\end{tabular}

Gambar 2. Susunan Acara Hari Kedua Tanggal 7 November 2019

\section{Hasil dan Pembahasan}

Kegiatan pelatihan MS.Office bagi siswa-siswi kelas 12 MA Raudatul Irfan dilaksanakan dengan cara tatap muka dan praktik mengerjakan latihan menggunakan aplikasi Ms.Word. Kegiatan berjalan lancar dan baik. Waktu pelaksanaan dilaksanakan selama dua hari, susunan acara dapat dilihat pada Tabel 1 dan 2.

Kegiatan menempati dua ruang lab komputer, karena jumlah peserta yang mencapai 80 siswa, sedangkan kapasitas lab hanya 40 buah komputer. Siswa yang datang terlebih dahulu mengisi daftar hadir. Kemudian masuk ke ruang lab 
computer UMN Gedung B pada hari pertama dan Gedung C pada hari kedua, duduk dengan satu komputer satu siswa. Pelatihan dibuka secara resmi oleh Direktur LPPM UMN Dr. PM. Winarno dan Kepala Sekolah MA Raudatul Irfan sekaligus menyampaikan sambutan terkait pentingnya kemampuan MS.Office. Pembukaan Kegiatan oleh Direktur LPPM UMN dan Kepala Sekolah MTS Raudatul Irfan disajikan pada Gambar 3.

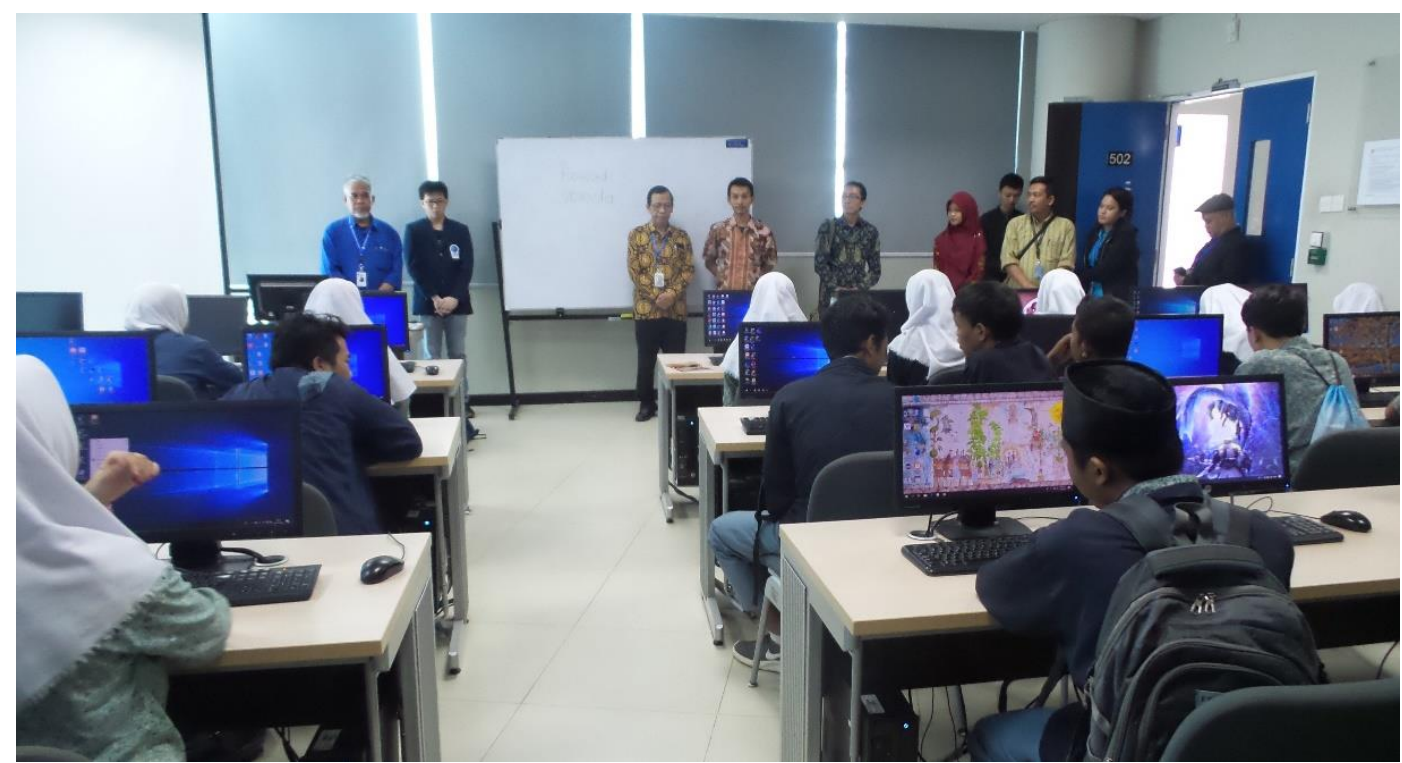

Gambar 3. Pembukaan Kegiatan oleh Direktur LPPM UMN dan Kepala Sekolah MTS Raudatul Irfan

Selanjutnya kegiatan pelatihan dimulai yang dipandu oleh dua orang dosen Informatika UMN setiap kelas, kegiatan ini sebagai bagian dari kegitan PKM. Para dosen berperan sebagai pemateri dibantu oleh mahasiswa informatika yang telah diseleksi dengan kemampuan MS.Office yang baik, para mahasiswa berjumlah 4 orang setiap kelas, dengan banyaknya pemateri dan mahasiswa dilakukan untuk mengantisipasi banyaknya pertanyaan dan kendala pada komputer yang biasa muncul pada waktu kegiatan berlangsung, seperti komputer tidak dapat menyala, mouse dan keyboard yang tidak terkoneksi dan lain-lain. Adapun metode yang digunakan dalam pelatihan dalam kelas adalah pemberian materi, diskusi, dan workshop/latihan. Pada metode pemberian materi, pemateri menyampaikan materi secara langsung kepada para peserta pelatihan yang diselingi dengan diskusi. Pada saat diskusi, peserta pelatihan diberi kesempatan untuk berdiskusi dengan sesama peserta dan pemateri. Metode selanjutnya yang digunakan adalah workshop. Pada tahap ini, para peserta pelatihan akan diberikan praktek langsung secara bersaamaan di lokasi pelatihan yang disajikan pada Gambar 4. 


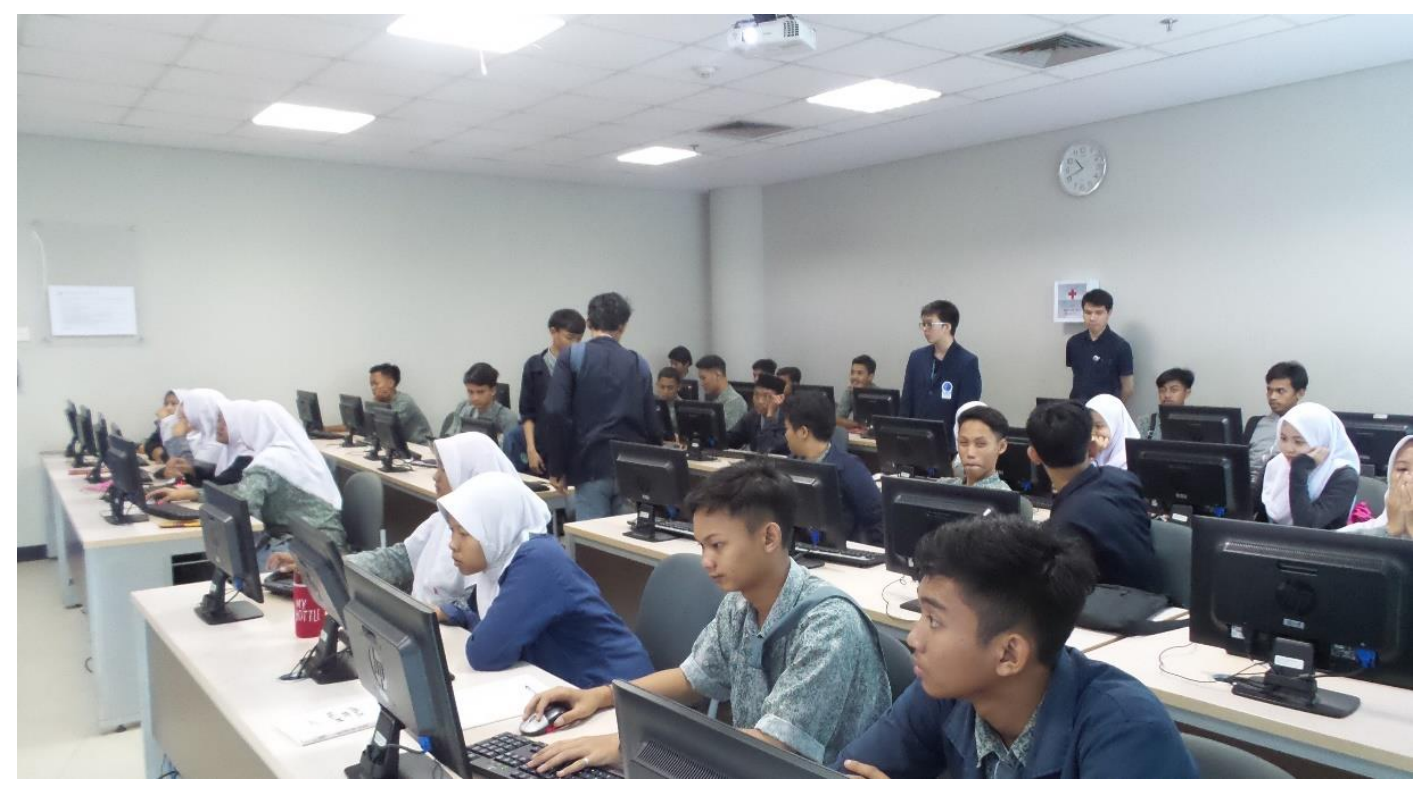

Gambar 4. Suasana Kegiatan Pelatihan

Materi yang disampaikan terdiri dari tiga sesi, dengan isi materi sebagai berikut:

1. Materi sesi 1 berisi:

- Pengantar MS.Word

- Word Format

- Word Art

- Tabel

- Membuat Surat Lamaran

- Membuat CV

2. Materi sesi 2 berisi:

- Daftar Isi

- New Section

- Membuat Makalah/Laporan

3. Materi sesi 3 berisi Ujian Akhir berisi perintah mengerjakan tugas MS.Word: Perintah Latihan yang diberikan:

Buat sebuah Proposal kegiatan sekolah seperti pensi/acara ulang tahun atau lomba. Proposal kegiatan disususun dengan menarik dan rapi. Dengan kriteria penilaian yang disajikan pada Tabel 1. 
Tabel. 1 Kriteria Penilaian

\begin{tabular}{clc}
\hline No & \multicolumn{1}{c}{ Kriteria Penilaian } & Nilai \\
\hline 1 & Jenis Kertas A4, Margin Kiri 3 dan Margin lainnya 3 & 5 \\
\hline 2 & Cover Proposal & 5 \\
\hline 3 & Membuat daftar isi dan nomor halaman secara otomatis & 5 \\
\hline 4 & $\begin{array}{l}\text { Section Landscape untuk Anggaran Biaya dan dalam bentuk } \\
\text { Tabel }\end{array}$ & 10 \\
\hline 5 & $\begin{array}{l}\text { Pemberian margin, efek, word art dan gambar/table/grafik } \\
\text { pada Proposal }\end{array}$ & 5 \\
\hline & $\begin{array}{l}\text { Struktur Proposal Kegiatan : Latar Belakang, Tujuan } \\
\text { Pelaksanaan, Tema Kegiatan, Nama Kegiatan, Bentuk }\end{array}$ & \\
\hline 6 & $\begin{array}{l}\text { Kegiatan, Waktu dan tempat Kegiatan, Susunan Acara } \\
\text { Kegiatan (Run Down), Peserta dan Juri (khusus untuk }\end{array}$ & 40 \\
\hline 7 & Pomba), Susunan Kepanitiaan, Estimasi Biaya dan Penutup . \\
\hline 8 & Isi laporan jelas, rapi dan daya kreatifitas & 5 \\
\hline 9 & Untuk Susunan Panitia menggunakan Column, dibagi dua. & 5 \\
\hline 10 & Jumlah Halaman Min. 4 Lembar termasuk cover & 10 \\
\hline
\end{tabular}

Di akhir kegiatan, diadakan survey dengan teknik wawancara kepada siswa dan guru MA Raudatul Irfan terkait kepuasan dalam mengikuti pelatihan dengan hasil bahwa pelatihan sangat bermanfaat bagi siswa dan terdapat peningkatan kemampuan dalam Ms.Word, dengan rekomendasi kegiatan akan dilanjutkan sebagai kegiatan rutin. Ada satu prinsip umum dan penting dalam kegiatan evaluasi, yaitu adanya triangulasi atau hubungan erat tiga komponen, yaitu antara: Pertama, tujuan pembelajaran. Kedua, kegiatan pembelajaran. Ketiga, evaluasi (Arikunto, 2019).

Pelaksanaan kegiatan pelatihan diukur dari beberapa point meliputi beberapa komponen sebagai berikut:

a. Capaian tujuan kegiatan secara keseluruhan sudah tercapai, hal ini dapat dilihat dari hasil latihan yang diadakan setiap akhir sesi, dengan rata-rata hasil baik.

b. Capaian kemampuan menguasai materi secara keseluruhan sudah tercapai, hal ini dapat dilihat dari hasil lembar evaluasi pelatihan, Menurut Gagne (Dahar, 2012) penampilan-penampilan yang dapat diamati sebagai hasil belajar disebut dengan kemampuan.

c. sebagian besar peserta sudah dapat menguasai materi pelatihan dengan baik yaitu rata-rata indeks prestasi 2,665 seperti terlihat pada Tabel 2 . 
Tabel. 2 Hasil Evaluasi Penelitian

\begin{tabular}{lc}
\hline $\begin{array}{c}\text { Nilai Huruf } \\
\text { [nilai Indeks Prestasi] }\end{array}$ & Jumlah Siswa \\
\hline A $[4,00]$ & 4 \\
\hline$A-[3,70]$ & 9 \\
\hline$B+[3,30]$ & 14 \\
\hline$B[3,00]$ & 13 \\
\hline$B-[2,70]$ & 10 \\
\hline$C+[2,30]$ & 9 \\
\hline$C[2,00]$ & 10 \\
\hline$D[1,00]$ & 11 \\
\hline$E[0,00]$ & 0 \\
\hline & Rata-rata Indeks Prestasi $=213,2 / 80=2,665$ \\
\hline
\end{tabular}

Dengan kemampuan dapat menyelesaikan latihan yang diberikan menggunakan fitur-fitur dari MS.Word pada materi-materi yang disampaikan selama pelatihan. Hasil Evaluasi berdasarkan Kriteria Penilaian disajikan pada Tabel 3.

Tabel.3 Hasil Evaluasi berdasarkan Kriteria Penilaian

\begin{tabular}{clc}
\hline No & \multicolumn{1}{c}{ Kriteria Penilaian } & \multicolumn{1}{c}{$\begin{array}{c}\text { Rerata } \\
\text { Nilai }\end{array}$} \\
\hline 1 & Jenis Kertas A4, Margin Kiri 3 dan Margin lainnya 3 & $56,46 \%$ \\
\hline 2 & Cover Proposal & $91,14 \%$ \\
\hline 3 & Membuat daftar isi dan nomor halaman secara otomatis & $51,39 \%$ \\
\hline 4 & $\begin{array}{l}\text { Section Landscape untuk Anggaran Biaya dan dalam } \\
\text { bentuk Tabel }\end{array}$ & $31,39 \%$ \\
\hline 5 & $\begin{array}{l}\text { Pemberian margin, efek, word art dan } \\
\text { gambar/table/grafik pada Proposal }\end{array}$ & $78,23 \%$ \\
\hline & $\begin{array}{l}\text { Struktur Proposal Kegiatan : Latar Belakang, Tujuan } \\
\text { Pelaksanaan, Tema Kegiatan, Nama Kegiatan, Bentuk }\end{array}$ & $\begin{array}{l}\text { Kegiatan, Waktu dan tempat Kegiatan, Susunan Acara } \\
6\end{array}$ \\
\hline & $\begin{array}{l}\text { Kegiatan (Run Down), Peserta dan Juri (khusus untuk } \\
\text { Penutup . }\end{array}$ & $72,94 \%$ \\
\hline 7 & Pemberian Bullet dan Numbering & $77,47 \%$ \\
\hline 8 & Isi laporan jelas, rapi dan daya kreatifitas & $72,03 \%$ \\
\hline 9 & $\begin{array}{l}\text { Untuk Susunan Panitia menggunakan Column, dibagi } \\
\text { dua. }\end{array}$ & $42,03 \%$ \\
\hline 10 & Jumlah Halaman Min. 4 Lembar termasuk cover & $89,24 \%$ \\
\hline
\end{tabular}


Tabel 3 menunjukkan secara umum fitur-fitur MS.Word yang disampaikan pada materi pelatihan sudah dapat dipahami dan dipraktikan secara baik namun ada beberapa fitur yang masih kurang dapat dipraktikan seperti pembuatan daftar isi secara otomatis, pengaturan penggabungan jenis orientasi landscape dan potrait dalam satu dokumen, serta penggunan kolom lebih dari satu.

d. Kemampuan peserta dalam mengoperasionalkan komputer sudah baik, hal ini ditunjukkan dari kemampuan peserta dalam menanggani kendala peralatan dan tidak adanya berarti kendala peralatan selama kegiatan.

Selain dari tingkat kebermanfaatan yang telah dipaparkan sebelumnya, dapat disimpulkan bahwa kegiatan pelatihan sangat bermanfaat bagi siswa dan guru. Peserta antusias untuk mengikuti kegiatan dengan memberikan saran untuk melanjutkan kegiatan di lain hari dengan waktu pelatihan yang lebih lama agar dapat lebih memahami advanced fitur dari MS.Word serta adanya kelanjutan program pelatihan untuk aplikasi di MS.Office lainnya, seperti MS.Excel, MS.Powerpoint.

\section{Kesimpulan}

Kegiatan pelatihan MS.Word bagi siswa-siswi MA Raudatul Irfan kelas 12 terlaksana dengan baik dan lancar sesuai rencana kegiatan, dan sebagian besar peserta pelatihan mampu menerima materi dengan baik. Peserta antusias dengan kegiatan pelatihan yang diadakan, hal ini dilihat dari keaktifan peserta pelatihan selama proses pelatihan berlangsung. Pelatihan yang dilakukan telah berhasil meningkatkan kemampuan siswa-siswi dalam memahami dan menguasai MS.Word. Sehingga dapat disimpulkan bahwa pelatihan bermanfaat dan akan dilanjutkan pada aplikasi MS.Office lainnya.

\section{Ucapan Terima Kasih}

Ucapan terima kasih diucapkan kepada Lembaga Penelitian dan Pengabdian Pada Masyarakat (LPPM) Universitas Multimedia Nusantara yang telah mendanai kegiatan pengabdian ini sehingga terlaksana dengan baik, kepada Guru MA Raudatul Irfan atas antusiasnya dan keinginan para siswa-siswinya untuk belajar.

\section{Referensi}

Arikunto, S. (2007). Dasar-Dasar Evaluasi Pendidikan. Jakarta: Bumi Aksara. Retrieved from http://library.fis.uny.ac.id/opac/index.php?p=show_detail\&id=7687

BPS. (2018). Badan Pusat Statistik. Retrieved October 6, 2020, from 
https://www.bps.go.id/pressrelease/2018/12/17/1532/indeks-pembangunanteknologi-informasi-dan-komunikasi--ip-tik--indonesia-tahun-2017-sebesar-499-pada-skala-0---10.html

Dahar, R. W. (2012). Teori-Teori Belajar dan Pembelajaran. Jakarta: Erlangga. Retrieved from http://ibrary.um.ac.id/free-contents/index.php/buku/detail/teori-teoribelajar-pembelajaran-ratna-wilis-dahar-40596.html

Dunlosky, J., Rawson, K. A., Marsh, E. J., Nathan, M. J., \& Willingham, D. T. (2013). Improving Students' Learning With Effective Learning Techniques: Promising Directions From Cognitive and Educational Psychology. Psychological Science in the Public Interest, 14(1), 4-58. https://doi.org/10.1177/1529100612453266

Fajriah, F. (2017). Learning Journal: Improving Teaching Strategies Through Students' Reflections. Sukma: Jurnal Pendidikan, 1(2), 301-327. https://doi.org/10.32533/01204(2017)

Hackathorn, J., Solomon, E. D., Blankmeyer, K. L., Tennial, R. E., \& Garczynski, A. M. (2011). Learning by Doing: An Empirical Study of Active Teaching Techniques. The Journal of Effective Teaching, 11(2), 40-54.

Hoque, E. (2016). Teaching Approaches, Methods, and Techniques. In International Conference on Language education and Research. Retrieved from https://www.researchgate.net/publication/315836577_Teaching_Approaches_Me thods_and_Techniques-_Enamul_Hoque

Jevana, R. J. (2017). Research On Effective Training Method In Organizations - A Millennials Need. International Journal of Innovative Research and Advanced Studies (IJIRAS) , 4(5), 300-305. Retrieved from https://www.researchgate.net/publication/319851805_Research_On_Effective_Tr aining_Method_In_Organizations_-_A_Millennials_Need

Martin, B. O., Kolomitro, K., \& Lam, T. C. M. (2014). Training Methods: A Review and Analysis. Human Resource Development Review, 13(1), 11-35. https://doi.org/10.1177/1534484313497947

Paolini, A. (2015). Enhancing Teaching Effectiveness and Student Learning Outcomes. The Journal of Effective Teaching, 15(1), 20-33. 